\title{
ПСИХОЛОГИЧЕСКИЕ И ПОЛИТТЕХНОЛОГИЧЕСКИЕ АСПЕКТЫ БАРХАТНОЙ РЕВОЛЮЦИИ В АРМЕНИИ
}

Татевян Г. А. (Армянский государственный педагогический университет им.

Х. Абовяна, Ереван, Армения) hrdatev@gmail.com

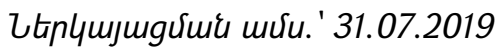

qnuһnuviuir шर्रu. '04.08.2019

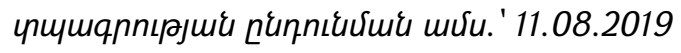

В статье рассматриваются особенности бескровной смены власти в Армении. Анализируется психологический фон и проявления массового сознания до, во время и после революционных процессов, примененные технологии и роль сетевых ресурсов. Данная проблема рассматривается в историческом аспекте, и проводится сравнение с последними бархатными революциями на постсоветском пространстве, в частности, в Украине.

Ключевые слова: власть, “бархатная револючия”, политические технологии, сетевые ресурсы, массовое сознание.

Через 30 лет после начала «Пражской весны», справедливо считающейся началом первой «бархатной» революции, и событий, предшествующих развалу Советского Союза, в Армении произошла бескровная смена власти. Через год мирная смена власти произошла и в Украине. Эти два события довольно примечательны как с психологической точки зрения, так и с точки зрения примененных политических технологий. Они имеют много общего, но в определенных аспектах в корне отличаются друг от друга.

Общее - то, что в обоих случаях смена власти произошла без жертв и посредством несфальсифицированных выборов. И все это имело место на фоне глубокого неприятия действующей власти. Однако пути достижения к этому существенно различались, примененные предвыборные технологии были диаметрально противоположны.

В Армении были массовые выступления, митинги, умеренные стычки с правоохранительными силами. А в Украине все проходило на удивление мирно и спокойно. Впервые, реально, не было необходимости проведения классической предвыборной кампании. По самой сути предвыборная кампания уже была проведена на протяжении трех лет, предшествующих выборам, благодаря заранее хорошо продуманному сериалу «Слуга народа». За эти три года демонстрации сериала, создавшего глубоко неприглядный образ власть придержащих, да еще на фоне ухудшения экономического состояния и наличия острых, неразрешенных проблем, особенно - связанных с Крымом и Донбасом, на полном основании можно было ожидать, что у подавляющей части населения будет такая психологическая установка по 
отношению к правящей элите, что голоса избирателей будут отданы новым лицам, никак не связанным с действующей властью. Что в итоге и произощло. Замечательное «ноу хау», приведшее к желаемому результату!

Данная смена власти в Армении мирным путем является второй в новейшей истории Армении. Первая была в 1989г., когда Армянское общенациональное движение победило коммунистов на парламентских выборах. После этого все попытки демократическим путем завоевать власть терпели неудачу - фральсифрицировались выборы, применялись различные силовые методы.

Хронологически первой фальсификацией результатов голосования со стороны демократически избранных новых властей была подтасовка голосов во время утверждения в парламенте нового герба Армении. Объявленое количество голосов «за» превысило общее количество депутатов, присутствующих в зале во время голосования.

После 1991г., когда на первых президентских выборах честную и безоговорочную победу одержал Л. Тер-Петросян, результаты всех последующих президентских (но и парламентских тоже) выборов вызывали, мягко говоря, серьезные сомнения. Властвующие лица и партии ни в коем случае и мысли не допускали, чтобы какимлибо образом отдать власть. После каждых таких выборов оспаривались результаты выборов, народ выходил на улицу. Наиболее жесткое подавление протестных действий случилось в 2008г., когда 1 марта погибло 10 человек.

Во время этих событий довольно активную и неоднозначную роль играл нынешний премьер-министр Никол Пашинян, который хорошо усвоил, допущенные ошибки и постарался их не допустить в длительной подготовке нынешней «бархатной» революции. Но в то время определенная прямолинейность действий оппозиции во много раз снизили эффеективность, а предсказуемость шагов позволили действующей власти принять адекватные и жесткие контрмеры, что в итоге привело к провалу попытки совершить «мирный переворот» в Армении. Употребление термина «переворот», вместо принятой “революции» не случаен, так как по большому счету революции кроме задачи захвата власти, в первую очередь, преследуют задачу смены политической системы, а бархатные революции - это только смена политического режима.

«Бархатная революция» в Армении проходила по всем классическим канонам современных бархатных революций, имевших место во многих странах мира. Применялись современные инструменты «мягкой силы» (soft power - Дж. С. Най), технологии мирных протестов, в частности - технологии, описанные Дж. Шарпом [3], были задействованы разнообразные сетевые ресурсы, активно использовались Facebook и другие социальные сети, была разработана специальная символика, применялись методы воздействия на массовое сознание и др.

Попытки представить события в Армении как уникальные, не имеющие аналога в мире, как спонтанного, заранее длительно и тщательно не 
подготовленного процесса, и осуществленного без существенных фринансовых затрат, по крайней мере, наивны. На первых порах новые власти все время твердили, что подготовкой занималась маленькая группа молодых энтузиастов и что у них не было необходимых средств! Однако, совсем недавно было заявлено, что было потрачено всего 200000 долларов (?!!). И это при условии, что по некоторым данным на дестабилизацию ситуации в Югославии за 1998 - 2000гг. только по каналам SEED в Сербию поступило около 100 млн. долларов, на цветные революции в Украине («оранжевая» революция) и Киргизии было потрачено 60 млн. и 50 млн., соответственно [4]. На пути к нынешней революции, были опробированы многие современные технологии и способы воздействия на индивидуальное сознание будущих, потенциальных участников массовых протестов. Использование сетевых ресурсов и способов ненасильственных активных действий явственно было видно во время массовых протестов в июне 2015 г., получивших название «Электрик - Ереван». При этом основным действующим лицом являлась молодежь. В 2017 г., во время предпоследних парламентских выборов политическая команда, возглавляемая Н. Пашиняном, активно использовала обращение к населению, что «в стране все зависит от одного человека, и этот человек - ТЫ». Многократное повторение данного лозунга имело целью (может на подсознательном уровне) пробудить личностную субъектность и чувство ответственности за принятые решения.

Молодежь являлась основной действующей силой не только в 2015г., но и во время массовых протестных действий 2018 г. Особенность молодежного составляющего была в том, что это - поколение, выросшее в годы независимости, с иным менталитетом, не отягощенное страхами старшего поколения, особенно перед советским КГБ. Новое поколение является носителем национального самосознания, весь советский период подавляемого тоталитарным режимом. Первый прорыв национальной идентичности и исторической памяти произошел в 1965г., в пятидесятилетие Геноцида армян. Следующее массовое проявление имело место уже в 1988г. в ходе Карабахского движения. Первоначальная массовая эйфория, связанная с надеждой на восстановление исторической справедливости в условиях коммунистической власти, вскоре прошла, и свои чаяния были перенаправлены на обретение независимости. С обретением независимости, столкнувшись с войной, экономическим крахом, народ постепенно растерял былую воодушевленность и веру в свои силы и возможности. Наиболее ощутимый удар жители Армении получили в условиях блокады, безработицы, несколько лет оставшись без газа и электричества и потеряв недавнюю веру в новые власти. В этих условиях у огромного количества людей, не имеющих достаточный объём психологических ресурсов приспособления к новым реалиям, развился синдром приобретенной беспомощности, что нашло свое прямое отражение в усилившихся темпах иммиграции, и самое примечательное, - в резком увеличении числа лиц, 
поставленных на психиатрический учет. Естественно, необходимо было время, чтобы сформировалось новое поколение с иным менталитетом, взглядом на жизнь и верой в свои силы. В своей книге, посвященной армянской бархатной революции, политолог Степан Григорян пишет, что «...после многих лет застоя и страха армяне начали улыбаться, обниматься и обмениваться приветствиями друг с другом» [1, с. 3]. Однако такое «братание», атмосфера всеобщей любви, стремления помочь друг другу присуще не только бархатной революции в Армении. Такие проявления имели место и раньше у нас (1988г.), и в других странах и в другие времена.

Так, например, в своей книге «Агрессивная толпа, массовая паника, слухи» А. Назаретян приводит описание психологического состояния петроградцев перед февральской революцией 1917 года, данное одним из очевидцев тех событий: «Все возбуждены, взволнованы, но не напуганы. Чувствую у себя и у прохожих, что мы все переживаем одно и то же - и это нас соединяет. Это состояние я чувствовал в течение нескольких дней и не могу определить его иначе, как ощущение какогото общего братства. Как будто пали обычные перегородки, отделяющие людей положением, состоянием, культурой, люди объединились и готовы помочь друг другу - в большом и малом; быть может, то было ощущение общего риска, которое соединяло всех. Случайные встречные разговаривали друг с другом, как давнишние приятели - дружески, доброжелательно, готовые прийти друг другу на помощь, если это даже связано с риском для жизни, о чем, вероятно, в ту пору никто не отдавал себе отчета. Это ощущение братства было очень острым и вполне определенным... То было воистину ощущениием общего народного праздника» [2, c. 28-29]. Так, что «Nil sub sole novum» (с лат.: «Ничто не ново под солнцем» Библия, Книга Экклезиаста, 1.10.). Еще одной примечательной особенностью армянской бархатной революции была монотемность. Изначально основным и единственным лозунгом являлось «сделай шаг, отвергни Сержа». Однако, после отставки Сержа Саркисяна, демонстранты сразу же начали скандировать «Никол варчапет /nремьер-министр, Г.Т./». Монотемность также имеет свою историю в Армении - «миацум /воссоединение, Г.Т.» в 1988 г. и «независимость» в 1990-1991 гг. Монотемность обладает мощным потенциалом, так как многократное «вдалбливание» сужает сознание, имеет медитативное воздействие и легко воспринимается людьми, даже с совершенно невысоким интеллектом.

Если к этому еще добавить постоянные напоминания о всеобщей любви со стороны лидера протестного движения, определенную символику (бейсболки с надписью «qnıluny" (духо'в - смело, Г.Т.), эксплуатацию образа местного Че, - с бородой и забинтованной рукой, то необходимое психологическое воздействие на массы было обеспечено.

Для успеха бархатных революций одной из решающих составляющих является позиция действующей власти. Если действующая власть сильна и не желает 
уступить, то от бархата ничего не остается и проливается кровь, как это уже имело место быть в 2008г. Слабость, нерешительность и медлительность властей напрямую играют на руку «бархатной» оппозиции. Но есть еще и другая сторона а нужно ли действующей власти на самом деле изо всех сил цепляться за свои должности, особенно, при наличии стоящих перед страной чрезвычайно сложных, взрывоопасных и судьбоносных проблем, которые рано или поздно власть должна решить. И тут снова напрашивается аналогия между сменой власти в Армении и Украине (проблемы Карабаха и Донбаса).

Заканчивая краткий обзор особенностей «бархатной» революции, искренне хочется пожелать новым властям успехов в преобразовании жизни в стране и достаточной мудрости, чтобы не повторялась ситуация из китайской притчи, когда герой убивший дракона, после посещения казны, сам становится новым драконом.

\section{Литература}

1. Григорян С.Г. Армянская бархатная революция: [Хронология и анализ событий]. Ереван, Эдит Принт, 2018, 174 с.

2. Назаретян А.П. Агрессивная толпа, массовая паника, слухи/Лекции по социальной и политической психологии. Питер, 2003. 189 с.

3. Sharp Gene, The Politics of Nonviolent Action (3 volumes). Boston, MA: Porter Sargent. 1973. 913 p.

4. https://gjugo.livejournal.com/1078.html

\section{PSYCHOLOGICAL AND POLITICAL-TECHNOLOGICAL ASPECTS OF THE VELVET REVOLUTION IN ARMENIA}

Tatevian H. A. (Armenian State Pedagogical University after Kh. Abovyan, Yerevan, Armenia)

The article touches upon the peculiarities of the non-violent change of regime in Armenia. The psychological background and manifestations of mass consciousness before, during and after the revolutionary processes, the technologies used and the role of network resources are analyzed. The given problem is being reviewed in the historical aspect and a comparison with the recent velvet revolutions in the post-soviet area, in the Ukraine, in particular, is being carried out.

Keywords: power, velvet revolution, political technologies, network resources, mass consciousness. 


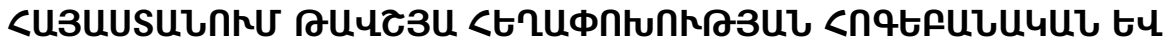

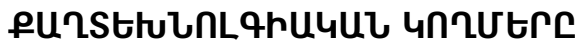

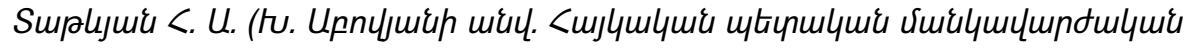

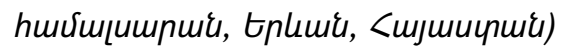

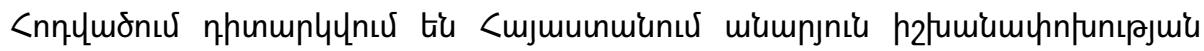

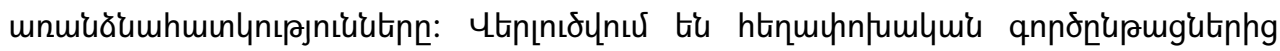

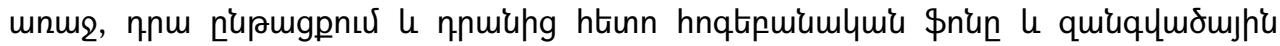

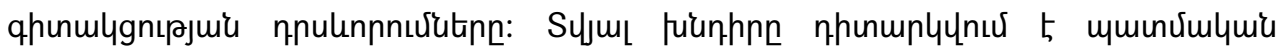

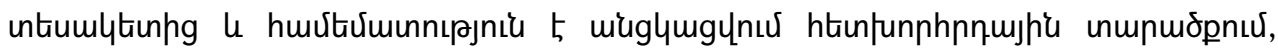

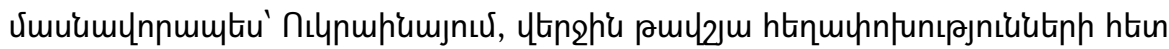

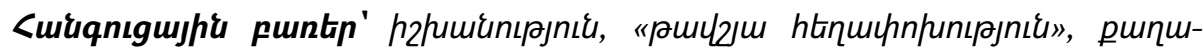

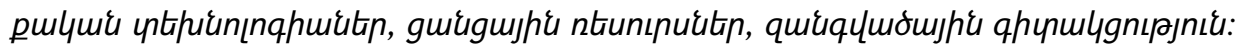

